\title{
Topical Emulsion Containing Lavandula stoechas Essential Oil as a Therapeutic Agent for Cutaneous Wound Healing
}

\author{
Mohamed Nadjib Boukhatem ${ }^{1,2, *(\mathbb{D})}$, Henni Chader ${ }^{3,4}{ }^{\text {, Aicha Houche }}{ }^{1}$, Faiza Oudjida ${ }^{5}$, Fatma Benkebaili ${ }^{1}$ \\ and Yahia Hakim ${ }^{6}$ \\ 1 Department of Biology, Faculty of Life and Natural Sciences, University Blida 1, Blida 09000, Algeria; \\ hoch.snv@gmail.com (A.H.); benkpharma@gmail.com (F.B.) \\ 2 Laboratoire Ethnobotanique et Substances Naturelles, Ecole Normale Supérieure, Kouba, Alger 16047, Algeria \\ 3 Laboratoire Pharmaco-Toxicologie, Laboratoire National de Contrôle des Produits Pharmaceutiques (LNCPP), \\ Dély Brahim, Alger 16047, Algeria; hennichader@outlook.fr \\ 4 Faculté de Médecine, Université Ben Youcef Ben Khedda, Alger I, Alger 16000, Algeria \\ 5 Laboratoire Anatomie Pathologique, Centre Hospitalo-Universitaire de Beni Messous, Alger 16206, Algeria; \\ biologie.microbio@yahoo.fr \\ 6 Extral-Bio Company, Chiffa, Blida 09000, Algeria; Extralbio2004@yahoo.fr \\ * Correspondence: mn.boukhatem@yahoo.fr; Tel.: +213-664983174
}

check for updates

Citation: Boukhatem, M.N.; Chader, H.; Houche, A.; Oudjida, F.; Benkebaili, F.; Hakim, Y. Topical Emulsion Containing Lavandula stoechas Essential Oil as a Therapeutic Agent for Cutaneous Wound Healing J 2021, 4, 288-307. https://doi.org/ $10.3390 / \mathrm{j} 4030023$

Academic Editors:

James David Adams and Maria Luisa Balestrieri

Received: 11 May 2021

Accepted: 29 June 2021

Published: 8 July 2021

Publisher's Note: MDPI stays neutral with regard to jurisdictional claims in published maps and institutional affiliations.

Copyright: (c) 2021 by the authors. Licensee MDPI, Basel, Switzerland. This article is an open access article distributed under the terms and conditions of the Creative Commons Attribution (CC BY) license (https:// creativecommons.org/licenses/by/ $4.0 /)$.

\begin{abstract}
Background and objectives: The present research was designed to evaluate the chemical composition of Lavandula stoechas essential oil (EOLS) as well as the in vivo wound-healing property. The chemical composition of EOLS was identified by gas chromatography mass spectrometry. Nineteen compounds of EOLS were reported. Linalool was identified as the major chemical compound $(24.87 \%)$, followed by linalyl acetate $(19.10 \%)$. EOLS showed a high content of oxygenated compounds $(63.54 \%)$. In vivo wound healing activity of the topical cream prepared from EOLS $(0.5 \% w / w)$ was assessed using a circular excision wound model. The wound area $\left(\mathrm{mm}^{2}\right)$ in all animal groups was estimated and measured on day $0,4,8,11$, and 16. Results: The EOLS formulation cream $(0.5 \% v / w)$ showed the highest effect on wound models when compared to reference Madecassol ${ }^{\circledR}$ (Asiaticoside). On days 4,11 , and 16 , wound contractions were $26.4 \%, 78 \%$, and $96.3 \%$ for the EOLS-treated group, and $8.5 \%, 64.1 \%$, and $86.1 \%$ for the vehicle cream-treated group. Animals treated with EOLS cream showed a significant decrease in the epithelization period, wound area, and scar thickness, whereas the rate of wound contraction significantly increased. This is the first such report to be published. Histological analyses were also consistent with the results of the excision experimental method. Treatment with EOLS cream formulation resulted in decreased inflammation and an increased rate of tissue perfusion and proliferation as well as remodeling, along with re-epithelization. Conclusions: Our results support the use of EOLS in the development of pharmaceuticals for the management of wounds, and/or inflammatory-related diseases. Additional studies are needed to elucidate and explain the exact mechanism of its pharmacological activity.
\end{abstract}

Keywords: Lavandula stoechas; essential oil; topical cream; wound healing; linalool

\section{Introduction}

Wound diseases and inflammatory-related illnesses have been more common in recent decades. Cure complexity, an increase in multidrug-resistant bacteria, side effects of medical therapies, and medication costs are both reasons for the need for the identification and development of new, efficient treatments with low toxicity and low cost [1]. Aromatic herbs and medicinal plants as well as volatile oils derived from them have long been used for therapeutic and medicinal uses [2]. Many papers and publications in recent years have identified the immense ability of these essential oils (EOs) and their chemical compounds, with several articles highlighting their antinociceptive, fungicidal, antioxidant, and antitumor properties [2-6]. 
EOs are being investigated for their wound healing properties, in addition to their antitumor and antimicrobial activities. Wound healing consists of a series of steps that repair the damaged tissue in part or completely. This repeated chain of reaction starts at the point of injury and lasts for varying lengths of time depending on the severity of the wounding. The use of aromatic plant and medicinal herb formulations, as well as phytochemical extracts, will help wound healing improvement in an optimized and effective way. Several stages of the healing process have been found to be influenced by these bioactive compounds. The terpenoid molecules in EOs, for example, are small enough to pass through the stratum corneum [7-9]. Based on the physical and chemical characteristics of the EO, it can be absorbed through the skin without a problem within 10 to $30 \mathrm{~min}$ [7-9].

Plant-derived EOs provide an enormous opportunity for the identification and creation of innovative drug leads in this context. Among such long-established wound healing medicines, the EO of the flowering aerial portion of butterfly lavender (Lavandula stoechas) holds a special place in African traditional medicine. Lavandula stoechas, also known as wild lavender, is a perennial flowering plant with aromatic leaves and beautiful bracts at the tops of the flowers [10,11]. Lavandula is a major genus of the Lamiaceae family that has over 39 recognized species and more than 450 produced hybrids. Though it is endemic to the Mediterranean region (Morocco, Algeria, Tunisia, Italy, France, and Spain), lavender has become cultivated around the world, and the numerous species provide us with a variety of EOs used in many applications in the food, cosmetic, pharmaceutical and fragrance industries. It is often used to make conventional meals and herbal teas, as well as for skin creams [10-12]. Several studies have been conducted to test the antimicrobial, antifungal, analgesic, antitumor, antiviral, antidepressant, and topical anti-inflammatory effects of EOLS [13-16].

The chemical composition and pharmacological evaluation of EOLS has been the subject of several studies over the years. However, there are very few systematic publications on its wound healing potential $[12,13]$. In the present investigation, the chemical composition of EOLS was determined using gas chromatography-mass spectrometry (GC-MS). Furthermore, we evaluated the wound healing potential of a new formulation of EOLS as a topical emulsion (dermal cream) by using an in vivo circular excision wound animal model. Madecassol (Asiaticoside), a registered therapeutic cream, was also included for comparison purposes.

\section{Materials and Methods}

2.1. Material

\subsubsection{Lavandula stoechas Essential Oil}

The EOLS used in this study was purchased from Extral-Bio Company (Chiffa, Blida, Algeria). The EO was obtained from fresh leaves, stems and inflorescences of Lavandula stoechas which were collected from the Cherchell state (coordinates $35^{\circ} 52^{\prime} 34^{\prime \prime} \mathrm{N}$ latitude and $0^{\circ} 17^{\prime} 2^{\prime \prime} \mathrm{W}$ longitude, Tipaza, Algeria) and steam-distilled for $2 \mathrm{~h}$. Before being used, the EOLS was held in a closed vial and stored at $4{ }^{\circ} \mathrm{C}$.

\subsubsection{Animals}

Male Wistar rats (160-200 g) were acquired from the "Laboratoire National de Contrôle des Produits Pharmaceutiques" (LNCPP, Algiers, Algeria). The animals were kept in a room for three days to acclimate. Throughout the trial, they were fed a normal pellet diet and given unlimited water. The animal study was carried out in compliance with the Algerian Executive Directive (18 March 2004, $\mathrm{N}^{\circ} 10-90$ JORA) and accordance also to the Law No. 88-08 of 26 January 1988 relating to veterinary medicine activities and the protection of animal health ( $\mathrm{N}^{\circ}$ JORA: 004 of 27-01-1988). 


\subsubsection{Drugs and Chemicals}

The following drugs and chemicals were used: Madécassol ${ }^{\circledR}(1 \%$ Asiaticoside, Roche, Montbrison, France), Tween 80 (IPA, Algiers, Algeria). All cosmetic ingredients (sweet almond oil, beeswax, stearic acid, cetylic alcohol (lanette 16), ceteareth-20 (emulgin B2), triethanolamine (trolamine), octyldodecanol (eutanol G), xanthan gum, stearyl alcohol and glycerin) were purchased from BASF Personal Care GmbH (Monheim, Germany).

\subsection{Methods}

\subsubsection{Determination of Chemical Composition of Essential Oil}

Analysis and identification of the volatile compounds were performed using a Shimadzu GC-17A gas chromatograph coupled with a Shimadzu QP-5050A MS detector (Shimadzu Corporation, Kyoto, Japan). The GC-MS system was equipped with a TRACSIL Meta.X5 (95\% dimethylpolysiloxane and 5\% diphenylpolysiloxane) column $(60 \mathrm{~m} \times 0.25 \mathrm{~mm}, 0.25 \mu \mathrm{m}$ film thickness; Teknokroma S. Coop. C. Ltd., Barcelona, Spain). Analyses were carried out using $\mathrm{He}$ as a carrier gas at a column flow rate of $0.3 \mathrm{~mL} / \mathrm{min}$ and a total flow of $3.9 \mathrm{~mL} / \mathrm{min}$ in a split ratio of 1:50 and the following program: (a) $50{ }^{\circ} \mathrm{C}$ for $0 \mathrm{~min}$; (b) increase of $3{ }^{\circ} \mathrm{C} / \mathrm{min}$ from $80{ }^{\circ} \mathrm{C}$ to $240{ }^{\circ} \mathrm{C}$ and hold for $1 \mathrm{~min}$; (c) increase of $25^{\circ} \mathrm{C} / \mathrm{min}$ from $240{ }^{\circ} \mathrm{C}$ to $300{ }^{\circ} \mathrm{C}$ and hold for $3 \mathrm{~min}$. The temperatures of the injector and detector were $230^{\circ} \mathrm{C}$ and $300^{\circ} \mathrm{C}$, respectively. All compounds were identified by comparison of their mass spectra with NIST05 and Wiley spectral library collections.

\subsubsection{In Vivo Wound Healing Activity}

Preparation of Test Samples for Bioassay

The tissue repair property was determined using an excision wound model (two rats per group). EOLS was formulated into a topical cream emulsion $(0.5 \%, w / w)$ for the in vivo wound models (Table 1). The abovementioned cream was made by precisely measuring the hydrophilic and lipophilic phase components, placing them in different beakers, and heating them. The lipophilic process was created by melting the waxes and emulsifiers (stearic acid, cetylic alcohol, stearyl alcohol and ceteareth-20) and constantly combining the substances. The water-soluble ingredients (octyldodecanol, xanthan gum and glycerin) were dissolved in deionized water to create the aqueous form. The two phases were heated to $65^{\circ} \mathrm{C}$ before all of the components were dissolved.

Table 1. Topical emulsion preparation with $0.5 \%$ of EOLS as a bioactive compound.

\begin{tabular}{cc}
\hline Ingredients & Quantity (\%) \\
\hline Lipophilic phase & \\
\hline Almond oil & $12-20$ \\
Beeswax & $3-5$ \\
Stearic acid & $6-8$ \\
Cetylic alcohol & $0.2-2$ \\
Stearyl alcohol & $0.2-1$ \\
Ceteareth-20 & $0.2-2$ \\
Lavandula stoechas essential oil & 0.5 \\
\hline Hydrophilic phase & \\
\hline Deionized water & $60-70$ \\
Octyldodecanol & $1-2$ \\
Glycerin & $3-5$ \\
Xanthan Gum & $0.1-0.3$ \\
Trolamine & 0.5 \\
\hline
\end{tabular}

When the oil and water phases were both at the same temperature $\left(65^{\circ} \mathrm{C}\right)$, the aqueous phase was gradually combined with the lipophilic phase while stirring until the cream melted and cooled. To create a semisolid cream base (Figure 1), the topical emulsion 
was cooled. Following the creation of a wound with a surgical instrument, a quantity of each test ointment was added topically to the wounded area. The animals in the vehicle group received only the cream base, while the rats in the positive control group received Madecassol ${ }^{\circledR} 1 \%$ (Asiaticoside) cream.

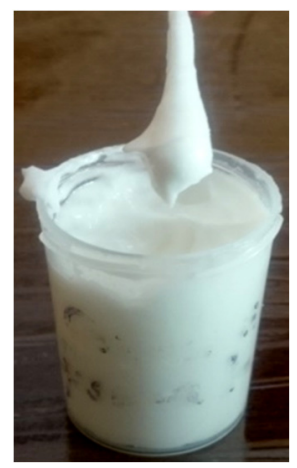

Figure 1. Lavandula stoechas essential oil topical cream formulation.

\section{Circular Excision Wound Model}

A spherical excision method has been used to track tissue repair and closure time. Each animal group was sedated with $0.01 \mathrm{~mL}$ of Thiopental Rotexmedica ${ }^{\circledR}$ (Sodium thiopental). Shaving was used to remove the animals' back hairs. Every animal had a superficial wound shaped on the dorsal inter-scapular area by excising the skin with a $2 \mathrm{~cm}$ biopsy punch; the wounds were left wide open [17].

The EOLS cream, the standard drug (Madecassol, 1\%), and the vehicle ointments base were applied topically once daily until the wound recovered properly (day 16). Every other day, translucent tracing paper was used to track the development of the wound region. Furthermore, the wound region was assessed using an AutoCAD method. Using the formula given, wound contraction was determined as a percent of the contraction in the wounded area:

$$
\% \text { wound contraction }=\left[\frac{\text { initial wound area }- \text { specific day wound area }}{\text { initial wound area }}\right] \times 100
$$

Each group of animals had a tissue sample obtained from the repaired skin for histology examination.

\section{Histology Examination}

On day 17 , the end of the study, skin samples from each group were isolated. Specimens were put in $10 \%$ buffered formalin, handled, and paraffin-blocked before being sectioned into 5 micrometer sections and stained with (hematoxylin and eosin) H\&E stains. A light microscope (Olympus CX41) was used to examine skin tissues, which were rated as medium $(+)$, intermediate $(++)$, or extreme $(+++)$ for epithelial or cutaneous remodeling. To score epithelial tissue or subcutaneous remodeling, re-epithelization or ulcers in the skin, fibroblast formation, polymorphonuclear cells, neo-vascularization, and collagen depositions in the layers of the skin were investigated. Ultimately, all tissue repair treatments were integrated and designed for wound healing processes such as infection, regeneration, and remodeling in all groups [17]. Histopathologic findings were deemed non-parametric, and no statistical study was carried out.

\subsection{Statistical Analysis}

Mean values of treated groups (EOLS and Madecassol creams) were compared with those of a vehicle group and analyzed using statistical tests. Comparison between different groups was carried out using the one-way analysis of variance (ANOVA). Differences with $p<0.05$ between experimental groups were considered statistically significant. Statistical data analysis was carried out using XLStat 2014 software (Addinsoft, Paris, France). 


\section{Results}

\subsection{Chemical Composition of Lavandula Stoechas Essential Oil}

In the present study, we evaluated the EO extracted from the aerial parts of Lavandula stoechas. Determination of the chemical composition of EOLS was carried out with GC-MS, and quantitative and qualitative compositions are shown in Table 2 and Figure 2. For EOLS, the main compound identified was linalool $(24.871 \%)$, followed by linalyl acetate $(19.10 \%)$, myrcene $(7.62 \%), \beta$-farnesene $(7.17 \%)$, and trans-caryophyllene $(6.37 \%)$. Other chemical terpenes were detected but were less than $6 \%$ (Table 2). Additionally, EOLS showed a high content of oxygenated monoterpenes $(56.7 \%)$ and low amounts of sesquiterpene hydrocarbons $(14.13 \%)$.

Table 2. Chemical composition of the volatile oil extracted from Lavandula stoechas using a steam distillation technique.

\begin{tabular}{|c|c|c|}
\hline $\mathbf{R T}^{\mathrm{b}}$ & Compounds $^{a}$ & $\%$ \\
\hline 8.842 & $\alpha$-Pinene & 0.44 \\
\hline 10.158 & Myrcene & 7.62 \\
\hline 10.808 & L-Limonene & 2.84 \\
\hline 11.000 & trans- $\beta$-Ocimene & 4.79 \\
\hline 11.191 & cis- $\beta$-Ocimene & 5.70 \\
\hline 11.328 & $\gamma$-Terpinene & 0.27 \\
\hline 12.204 & Linalool & 24.87 \\
\hline 12.763 & Camphor & 0.13 \\
\hline 13.303 & Terpineol-4 & 5.15 \\
\hline 13.476 & $\alpha$-Terpineol & 1.92 \\
\hline 14.481 & Linalyl acetate & 19.10 \\
\hline 15.865 & Neryl acetate & 1.86 \\
\hline 16.128 & Geranyl acetate & 3.73 \\
\hline 16.640 & trans-Caryophyllene & 6.35 \\
\hline 17.062 & $\beta$-Farnesene & 7.17 \\
\hline 17.673 & $\beta$-Bisabolene & 0.17 \\
\hline 17.861 & $\delta$-Cadinene & 0.10 \\
\hline 18.570 & Caryophyllene oxide & 0.20 \\
\hline \multirow[t]{6}{*}{19.246} & $\delta$-Cadinol & 0.14 \\
\hline & Monoterpene hydrocarbons & 21.66 \\
\hline & Oxygenated monoterpenes & 56.76 \\
\hline & Sesquiterpene hydrocarbons & 13.79 \\
\hline & Oxygenated sesquiterpenes & 0.34 \\
\hline & Total identified & 92.55 \\
\hline
\end{tabular}

\footnotetext{
${ }^{a}$ Compounds listed in order of elution from a nonpolar DB-5 column. ${ }^{b}$ RT: retention times (min).
} 


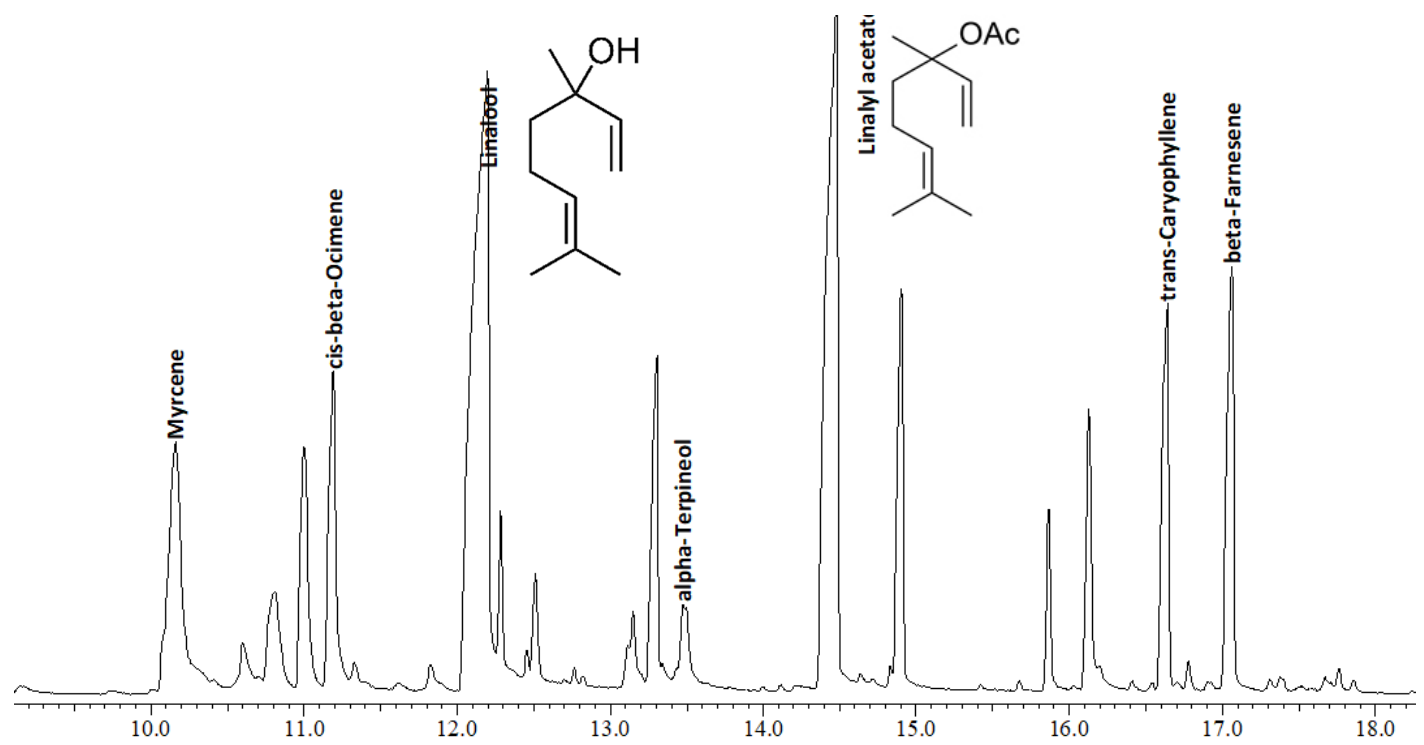

Figure 2. GC-MS chromatogram obtained from Lavandula stoechas essential oil.

The chemical composition of EOLS varies from that of many other Lavandula species and hybrids found in the Mediterranean region. The primary constituents of EOLS are oxygenated monoterpenes such as linalool, camphor, 1,8-cineol, terpineol, linalyl acetate and terpinene-4-ol. The chemical composition of EOLS has been investigated in various Mediterranean countries (Algeria, Greece, France, Tunisia, Italy, and Turkey), with varying results (Table 3).

Table 3. Major chemical compounds EOLS from different regions.

\begin{tabular}{|c|c|c|c|c|}
\hline Country & $\begin{array}{c}\text { Plant } \\
\text { Material }\end{array}$ & $\begin{array}{l}\text { Extraction } \\
\text { Method }\end{array}$ & Major Compounds (\%) & References \\
\hline \multirow{6}{*}{ Algeria } & $\begin{array}{l}\text { Dried and finely powdered } \\
\text { aerial parts (leaves and } \\
\text { flowers) } \\
\text { Flowering period }\end{array}$ & $\begin{array}{l}\text { Hydrodistillation } \\
\text { (HD) }\end{array}$ & $\begin{array}{l}\text { Fenchone }=31.6 \\
\text { Camphor }=22.4 \\
p \text {-Cymene }=6.5\end{array}$ & $\begin{array}{l}\text { Dob } \\
\text { et al. [18] }\end{array}$ \\
\hline & Air dried aerial parts & HD & $\begin{array}{l}\text { Fenchone }=50.29 \\
\text { Camphor }=14.02 \\
\text { Bornyl acetate }=5.60\end{array}$ & $\begin{array}{l}\text { Baali } \\
\text { et al. [19] }\end{array}$ \\
\hline & $\begin{array}{l}\text { Aerial parts } \\
\text { (leaves, stems, flowers) }\end{array}$ & Alembic steam distillation. & $\begin{array}{l}1,8-\text { Cineol }=61.36 \\
\beta \text {-Pinene }=13.83 \\
\alpha \text {-Pinene }=4.75\end{array}$ & $\begin{array}{l}\text { Boukhatem } \\
\text { et al. [20] }\end{array}$ \\
\hline & $\begin{array}{l}\text { Dried plants } \\
\text { (leaves) }\end{array}$ & HD & $\begin{array}{l}\text { Fenchone }=25.48 \\
\text { Camphor }=24.44 \\
\text { Pulegone }=5.81\end{array}$ & $\begin{array}{l}\text { Yakoubi } \\
\text { et al. [21] }\end{array}$ \\
\hline & Dried flowers & HD & $\begin{array}{l}\text { Fenchone }=40.78 \\
\text { Camphor }=9.76 \\
\text { Myrtenyl acetate }=8.94 \\
\text { Bornyl acetate }=5.1\end{array}$ & $\begin{array}{l}\text { Loukhaoukha } \\
\text { et al. [22] }\end{array}$ \\
\hline & Dried flowers & HD & $\begin{array}{l}\text { Linalyl acetate }=15.26 \\
\text { Linalool }=10.68 \\
1,8 \text {-Cineol }=10.25 \\
\gamma \text {-Terpinene }=11.2\end{array}$ & $\begin{array}{l}\text { Barkat and } \\
\text { Laib [23] }\end{array}$ \\
\hline \multirow[b]{2}{*}{$\begin{array}{l}\text { Crete } \\
\text { (Greece) }\end{array}$} & Dried aerial part & Steam distillation & Fenchone $=30.85$ & $\begin{array}{l}\text { Kokkalou } \\
\text { [24] }\end{array}$ \\
\hline & $\begin{array}{l}\text { Air dried aerial part (leaves, } \\
\text { inflorescences) }\end{array}$ & HD & $\begin{array}{l}\text { Fenchone }=44.8 \\
1,8-\text { Cineol }=16.7 \\
\alpha \text {-Cadinol }=7.4 \\
\text { Camphor }=6.2 \\
\alpha \text {-Pinene }=2.2\end{array}$ & $\begin{array}{l}\text { Skoula } \\
\text { et al. [25] }\end{array}$ \\
\hline
\end{tabular}


Table 3. Cont.

\begin{tabular}{|c|c|c|c|c|}
\hline Country & $\begin{array}{c}\text { Plant } \\
\text { Material }\end{array}$ & $\begin{array}{l}\text { Extraction } \\
\text { Method }\end{array}$ & Major Compounds (\%) & References \\
\hline $\begin{array}{l}\text { Corsica } \\
\text { (France) }\end{array}$ & Fresh material & HD & $\begin{array}{l}\text { Fenchone }=31.6-75.5 \\
\text { Camphor }=9.1-28.4 \\
1,8-\text { Cineol }=17.8\end{array}$ & $\begin{array}{l}\text { Ristorcelli } \\
\text { et al. [26] }\end{array}$ \\
\hline $\begin{array}{l}\text { Sardinia } \\
\text { (Italy) }\end{array}$ & Air-dried aerial part & HD & $\begin{array}{l}\text { Fenchone }=37 \\
\text { Camphor }=27.3 \\
\text { Bornyl acetate }=6.2 \\
1,8 \text {-Cineol }=6\end{array}$ & $\begin{array}{l}\text { Zuzarte } \\
\text { et al. [27] }\end{array}$ \\
\hline Portugal & $\begin{array}{l}\text { Aerial parts } \\
\text { (leaves and flowers) of } L . \\
\text { stoechas subsp. Luisieri }\end{array}$ & HD & $\begin{array}{l}\text { Dormancy stage } \\
\text { trans }-\alpha-N e c r o d y l \text { acetate }=12.58 \\
\text { Fenchone }=5.97 \\
\text { trans }-\alpha-N e c r o d o l=5.22 \\
\text { Flowering stage } \\
\text { trans }-\alpha-N e c r o d y l \text { acetate }=26.90 \\
\text { trans }-\alpha-N e c r o d o l=13.02 \\
\text { Lavandulyl acetate }=6.53\end{array}$ & $\begin{array}{l}\text { Domingues } \\
\text { et al. [28] }\end{array}$ \\
\hline \multirow[t]{2}{*}{ Tunisia } & $\begin{array}{l}\text { Air-dried aerial parts } \\
\text { (stems, leaves) } \\
\text { Vegetative stage. }\end{array}$ & HD & $\begin{array}{l}\text { Fenchone }=34.3 \\
\text { Camphor }=27.4 \\
\text { Lavandulyl acetate }=5.6\end{array}$ & $\begin{array}{l}\text { Messaoud } \\
\text { et al. [29] }\end{array}$ \\
\hline & Air-dried aerial parts & HD & $\begin{array}{l}\text { Linalyl acetate }=64.30-7.55 \\
\text { Linalool }=20.25-3.21 \\
\beta \text {-Thuyone }=8.97-0.99\end{array}$ & $\begin{array}{l}\text { Msaada } \\
\text { et al. [30] }\end{array}$ \\
\hline \multirow{8}{*}{ Turkey } & Flowers & $\begin{array}{c}\mathrm{CO}_{2} \text { Supercritical fluid } \\
\text { extraction }\end{array}$ & $\begin{array}{l}\text { Camphor }=58.8 \\
\text { Fenchone }=33 \\
\alpha \text {-Pinene }=3.5 \\
\alpha \text {-Cadinol }=0.2\end{array}$ & \multirow{2}{*}{$\begin{array}{l}\text { Akgün } \\
\text { et al. [31] }\end{array}$} \\
\hline & Flowers & $\begin{array}{l}\text { Solvent extraction } \\
\text { (Soxhlet) }\end{array}$ & $\begin{array}{l}\text { Camphor }=41.3 \\
\text { Fenchone }=31.3 \\
\alpha \text {-Cadinol }=11.7 \\
\alpha \text {-Pinene }=2.6\end{array}$ & \\
\hline & \multirow{3}{*}{$\begin{array}{l}\text { Dried flowers } \\
\text { (flowering stage) }\end{array}$} & $\begin{array}{l}\text { Sub-critical water } \\
\text { extraction }\end{array}$ & $\begin{array}{l}\text { Camphor }=29.64 \\
\text { Fenchone }=26.93 \\
1,8-\text { Cineol }=4.38\end{array}$ & \multirow{3}{*}{$\begin{array}{l}\text { Giray } \\
\text { et al. [32] }\end{array}$} \\
\hline & & $\begin{array}{l}\text { Ultrasound assisted } \\
\text { extraction }\end{array}$ & $\begin{array}{l}\text { Camphor }=41.09 \\
\text { Fenchone }=34.23 \\
\text { Myrtenyl acetate }=4.97\end{array}$ & \\
\hline & & HD & $\begin{array}{l}\text { Fenchone }=32.03 \\
\text { Camphor }=14.71 \\
\text { Myrtenyl acetate }=11.70 \\
1,8-\text { Cineol }=7.67\end{array}$ & \\
\hline & Air dried leaves and flowers & HD & $\begin{array}{l}\text { Leaves } \\
\alpha \text {-Fenchone }=41.9 \pm 1.2 \\
1,8 \text {-Cineol }=15.6 \pm 0.8 \\
\text { Camphor }=12.1 \pm 0.5 \\
\text { Viridiflorol }=4.1 \pm 0.4 \\
\text { Flowers } \\
\alpha \text {-Fenchone }=39.2 \pm 0.9 \\
\text { Myrtenyl acetate }=9.5 \pm 0.4 \\
\alpha \text {-Pinene }=6.1 \pm 0.09 \\
\text { Camphor }=5.9 \pm 0.05 \\
1,8 \text {-Cineol }=3.8 \pm 0.1\end{array}$ & $\begin{array}{l}\text { Kirmizibekmez } \\
\text { et al. [33] }\end{array}$ \\
\hline & Leaves & HD & $\begin{array}{l}\text { Pulegone }=40.37 \\
\text { Menthol }=18.09 \\
\text { Menthone }=12.57 \\
\text { Eucalyptol }=3.9\end{array}$ & $\begin{array}{l}\text { Gören } \\
\text { et al. [34] }\end{array}$ \\
\hline & Air dried leaves & HD & $\begin{array}{l}1,8-\text { Cineol }=35.5 \\
\text { Camphor }=20.2 \\
\alpha \text {-Thujone }=15.9\end{array}$ & $\begin{array}{l}\text { Bozkurt } \\
\text { et al. [35] }\end{array}$ \\
\hline
\end{tabular}


Table 3. Cont.

\begin{tabular}{|c|c|c|c|c|}
\hline Country & $\begin{array}{c}\text { Plant } \\
\text { Material }\end{array}$ & $\begin{array}{l}\text { Extraction } \\
\text { Method }\end{array}$ & Major Compounds (\%) & References \\
\hline & $\begin{array}{l}\text { Aerial part } \\
\text { (flowering season) }\end{array}$ & HD & $\begin{array}{l}\text { Camphor }=48.1 \\
\text { Fenchone }=30.5 \\
\text { Muurolol }=5.72\end{array}$ & $\begin{array}{l}\text { Karan } \\
\text { et al. [36] }\end{array}$ \\
\hline Morocco & $\begin{array}{l}\text { Dried aerial part } \\
\text { (leaves) }\end{array}$ & HD & $\begin{array}{l}\text { 10s,11s-himachala-3(12),4-diene } \\
=23.62 \\
\text { Cubenol = } 16.19 \\
\text { Methyl eugenol = } 6.19\end{array}$ & $\begin{array}{l}\text { Cherrat } \\
\text { et al. [37] }\end{array}$ \\
\hline \multirow[t]{2}{*}{ Iran } & Air-dried flowers & HD & $\begin{array}{l}\text { Linalool }=35.69 \\
\text { Borneol }=14.99 \\
1,8-\text { Cineol }=11.45 \\
\text { Camphor }=4.32 \\
4 \text {-Terpineol }=3.72\end{array}$ & $\begin{array}{l}\text { Khavarpour } \\
\text { et al. [38] }\end{array}$ \\
\hline & Shade dried flowers & Steam distillation & $\begin{array}{l}\text { Camphor }=71.8 \\
1,8-\text { Cineol }=4.08 \\
\text { Linalool }=3.77 \\
\text { Borneol }=3.19\end{array}$ & $\begin{array}{l}\text { Asghari } \\
\text { et al. [39] }\end{array}$ \\
\hline
\end{tabular}

The aromatic compounds of lavender identified in this analysis were both comparable and divergent to those recorded in previous research [18-30]. For example, our findings are consistent with those of Chebil et al. [40], who found that linalool and linalyl acetate were the most abundant oxygenated terpenes in Tunisian EO. In contrast, a comprehensive review of Indian EOLS revealed that camphor, fenchone, and eucalyptol (1,8-cineol) were the key chemical compounds [41]. Ristorcelli et al. [26] identified the chemical composition of 50 samples of EOLS from different places of Corsica during the flowering stage; they discovered significant differences in the major components: fenchone, $15-75 \%$; camphor, 2-56\%; and 1,8-cineol, 1-8\%. Nonetheless, the EOLS collected from a different Turkish area [34] tended to be of a peculiar chemotype distinguished by the existence of menthone (12.6\%), menthol (18.1\%), and pulegone (40.2\%).

As previously mentioned, variations in the chemical composition of EOs presented in several reports and publications are most likely due to differences in distillation operational conditions as well as the chemical components of lavender, which are affected by plant types and varieties, phenological transformations, storage, extraction methods, climatic and growth conditions, and harvesting time [11,16,42].

Granger et al. [43] studied eight samples of EOLS from different areas (Southern France, Corsica, Spain, and Turkey). All EOs were characterized by the importance of camphor and/or fenchone, which represented $74-98 \%$ of the EO, with one or the other ketone predominant.

The comparison of EO chemical composition among the analyzed Lavandula species indicated that numerous components such as carvacrol, thymol, limonene, farnesene and thymol methyl ether, were restricted to Lavandula multifidi and L. coronopifolia. Additionally, all major L. stoechas constituents (fenchone, comphor and lavandulyl acetate) and a number of minor ones (eucalyptol, borneol, bornyl acetate, myrtenyl acetate, and cadalene) were absent in L. coronopifolia and L. multifida. This chemical difference across species implies that the concentration of organic compounds may be useful in assessing chemotaxonomy. The chemical compositions of lavender essential oils vary greatly due to environmental factors such as latitude, atmospheric pressure, relative humidity, and precipitation, which influence the relative chemical substances in the oil based on how, where, and when the plant was grown and collected [44,45]. The percentage of linalool, the oil's main chemical component, has been observed to be altered significantly in response to fluctuations in various environmental conditions. For illustration, scientists found one population of lavender cultivated in North Greece with linalool percentages fluctuating from $48.71 \%$ to $35.1 \%$ over a few weeks due to temperature changes and the duration since the most recent precipitation. 


\subsection{In Vivo Pharmacological Evaluation of Wound Healing Effect}

\subsubsection{Effect of Lavender Essential Oil on Percent Wound Contraction and Area}

The use of EOs in skincare is rapidly expanding around the globe. Due to the extreme renewed interest in phytochemicals such as EOs, it is important to understand their potential in wound healing for application areas in human wellbeing and health. On days $0,4,8,11$, and 16 , the wound area $\left(\mathrm{mm}^{2}\right)$ was determined and analyzed in all animal types (Figure 3). When compared to the control group, animals treated with EOLS cream formulation $(0.5 \%, w / w)$ had a smaller wound area.



Figure 3. Effect of EOLS cream formulation treatment on wound area $\left(\mathrm{mm}^{2}\right)$ in rats. * significant difference; ns: not significant.

Figure 4 illustrates the wound-healing development as a result of wound contraction. When EOLS topical emulsion was applied to rats, the percent wound contraction rate improved when compared to control group animals (Figure 5). In the excision wound model, the EOLS formulation cream was shown to have therapeutic potential, while the vehicle group had no substantial wound healing activity. On days 4, 11, and 16, wound contractions were $26.4 \%, 78 \%$, and $96.3 \%$ for the EOLS-treated group, and $8.5 \%, 64.1 \%$, and $86.1 \%$ for the vehicle cream-treated group.

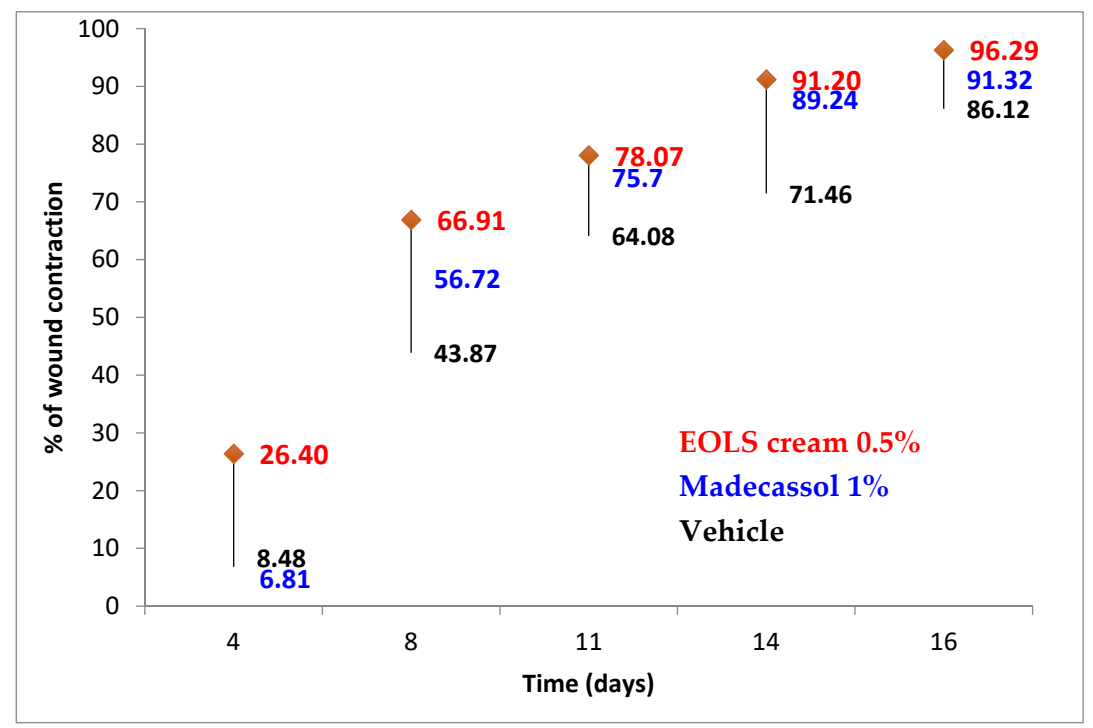

Figure 4. Effect of EOLS cream formulation treatment on rate of wound contraction in rats. 

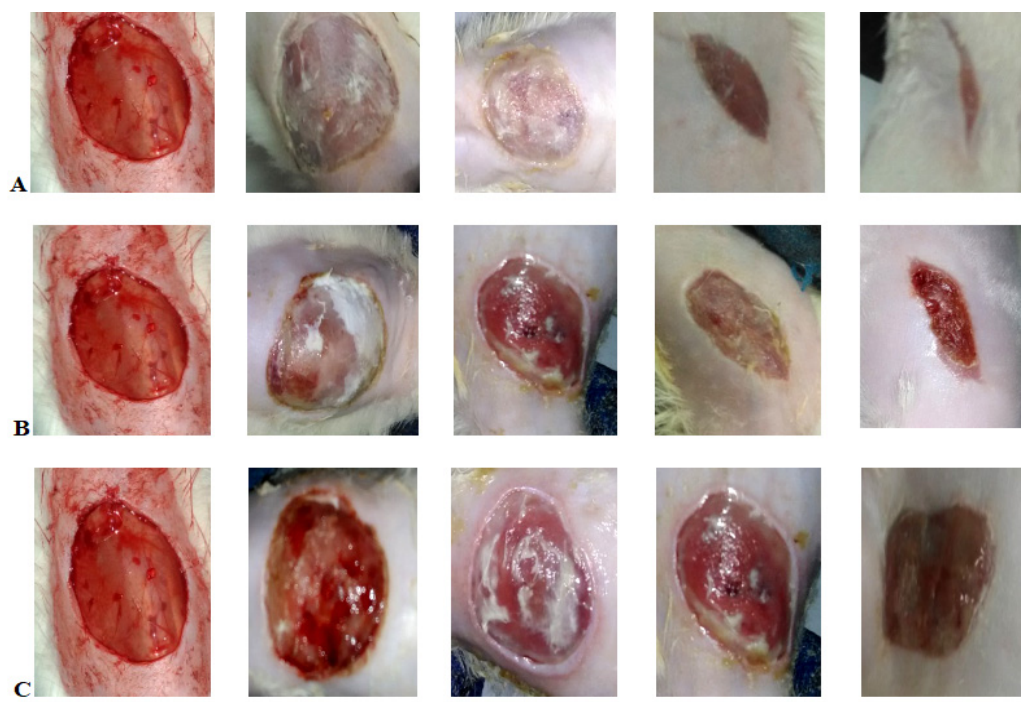

Figure 5. Photographs of rats (dorsal region) showing various phases of wound healing. (A): EOLS cream formulation $(0.5 \% w / w)$; (B): positive control (Madecassol ${ }^{\circledR}$ cream $\left.1 \%\right)$; (C): vehicle.

\subsubsection{Histological Examination}

Histopathology was performed on skin samples. Histological analyses supported the findings of the excision experimental study. Representative photomicrographs (Figure 6) stained with H\&E were also used to demonstrate the wound healing phase. Among the experimental classes, different stages of wound healing processes were studied. Among the experimental groups, wound healing stages (inflammation, proliferation, and remodeling) were observed and documented (Table 4). Wound healing processes were delayed in the negative control group, while quicker remodeling was found in the test groups in different degrees.
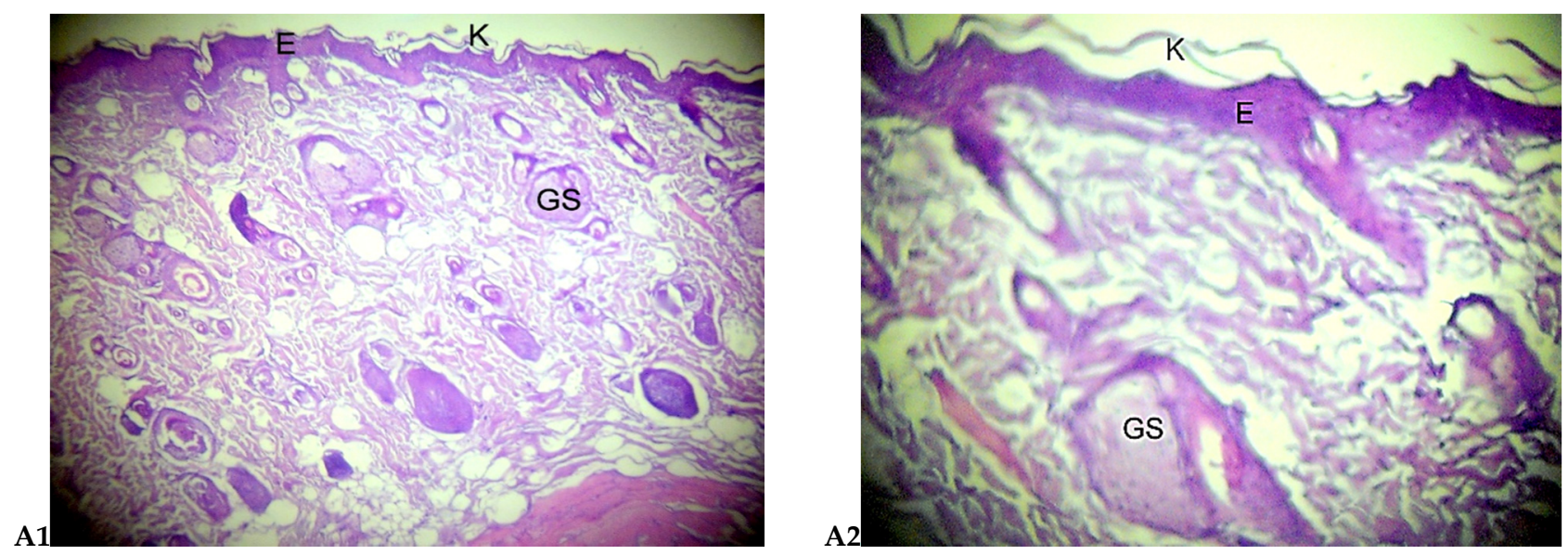

(A) Skin microscopic image of normal rats: A1 (X10), A2 (X40)

Figure 6. Cont. 

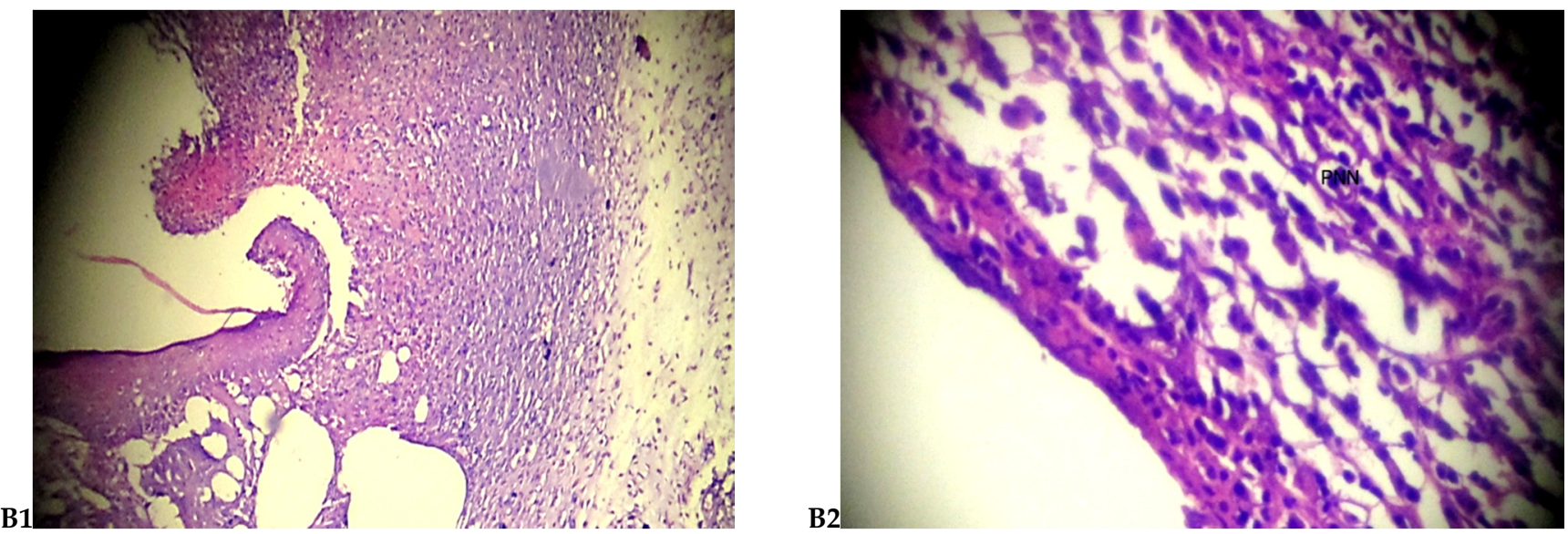

(B) Vehicle group, 11-day-old wound tissue treated with only vehicle: B1 (X10), B2 (X40)
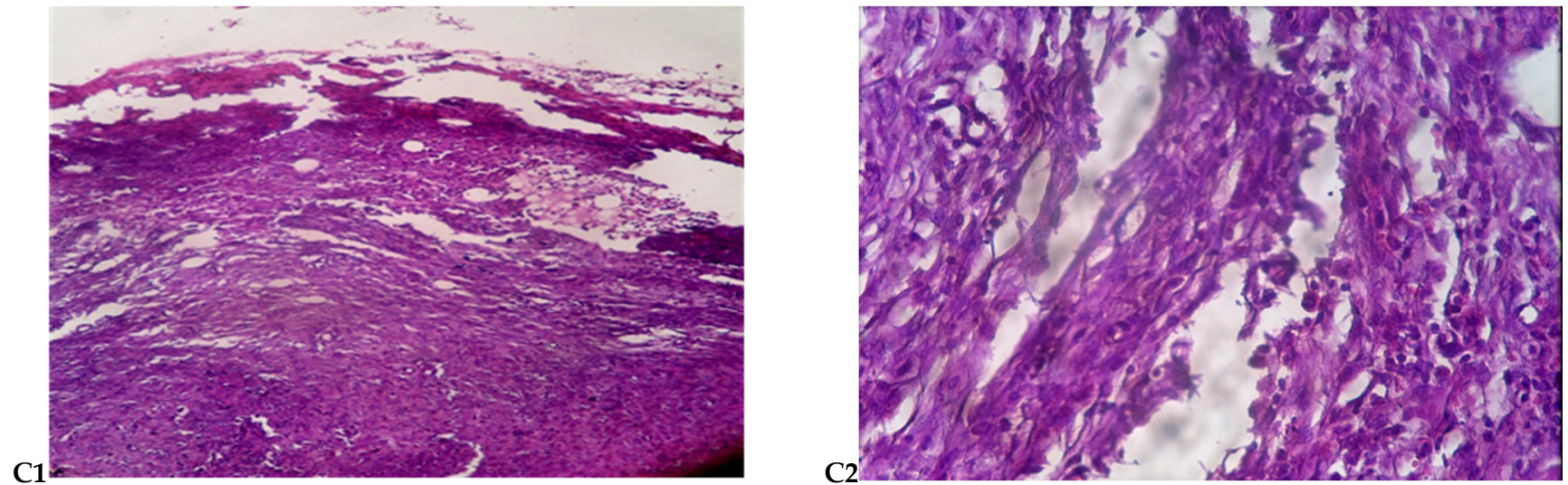

(C) Reference group, 17-day-old wound tissue treated with Madecassol ${ }^{\circledR}:$ C1 (X10), C2 (X40)
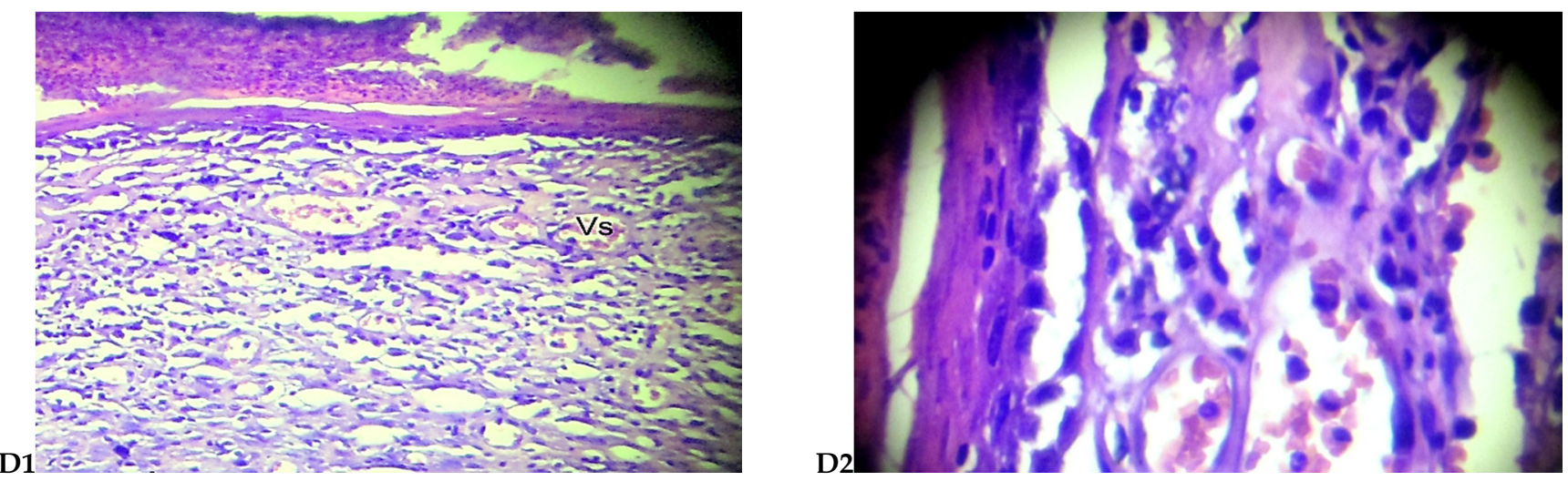

(D) Eleven-day-old wound tissue treated with the EOLS cream formulation: D1 (X10), D2 (X40)

Figure 6. Cont. 

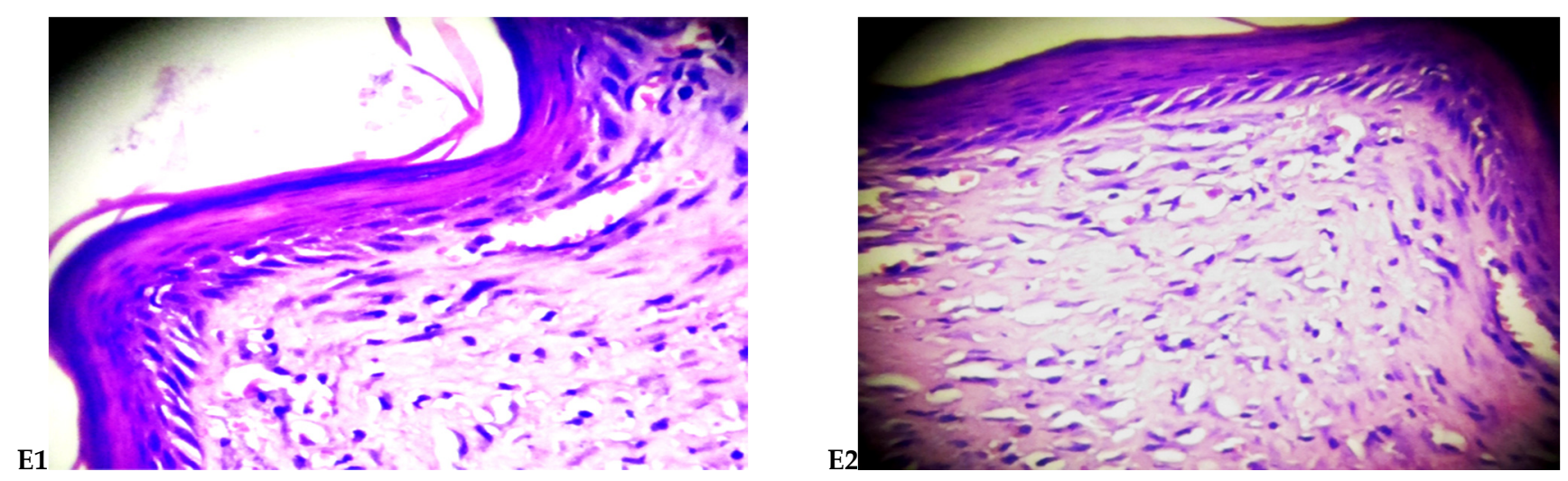

(E) Seventeen-day-old wound tissue treated with the EOLS topical cream formulation: E1 (X10), E2 (X40); E: epidermal layer, Ep: epithelium. Gs: sebaceous gland. K: kratin. PNN: neutrophil polynuclear cells. Vs: blood vessels.

Figure 6. Photomicrographs of sections of skin from rats stained with H\&E. Skin microscopic image of (A) normal rat, (B) wound control rat, (C) positive control rat, and (D,E) EOLS topical cream formulation-treated rat.

Table 4. Wound healing processes and healing phases of the vehicle, EOLS cream, and Madecassol ${ }^{\circledR}$ administered to rats.

\begin{tabular}{cccccccccccc}
\hline & \multicolumn{4}{c}{ Wound Healing Processes } & \multicolumn{4}{c}{ Healing Phases } \\
\hline Groups & S & U & RE & FP & CD & PMN & NV & I & P & R \\
\hline Vehicle & +++ & ++ & $-/+$ & +++ & ++ & ++ & ++ & + & +++ & $-/+$ \\
EOLS & ++ & + & ++ & ++ & ++ & + & ++ & + & ++ & ++ \\
Madecassol $^{\circledR}$ & $+/++$ & - & +++ & + & +++ & $-/+$ & + & + & + & ++ \\
\hline
\end{tabular}

Hematoxylin- and Eosin-stained sections were scored as mild (+), moderate (++) and severe (+++) for epidermal and/or dermal remodeling. EOLS: Lavandula stoechas essential oil, S: scab, U: ulcus, RE: re-epithelization, FP: fibroblast proliferation, CD: collagen depositions, PMN: polymorphonuclear cells, NV: neovascularization, I: inflammation phase, P: proliferation phase, R: remodeling phase.

Various steps in wound healing processes were observed during the experimental period, including inflammation, regeneration, and remodeling. In the negative control group, there were delays in wound repair processes, as well as inflammation, monocyte cells, and cellular necrosis (Figure 6B). Histological analysis of this group revealed macrophage aggregation with poor collagenation. The dermis had a high number of fibroblasts, while the control had less new blood vessel formations. Accumulation of collagen, connective tissues, and blood vessels with epidermal covering at the wound margin was observed in the EOLS topical cream formulation-treated group (Figure 6D,E). Treatment with this EOLS cream formulation resulted in reduced inflammation, enhanced tissue perfusion and regeneration, remodeling, and re-epithelization. In the EOLS cream formulation-treated animals, there were less macrophage and more collagen fibers, with less scar formation. Ben Djemaa et al. [13] demonstrated that the topical application of Lavandula aspic volatile oil raises the amount of epithelial cells and has a great influence on the closure of the wound.

Our data indicate that EOLS topical cream formulation could aid in the rapid healing of acute and chronic wounds by preserving the injury site from infections, inhibiting inflammatory cells, and forming connective tissue in the healed tissue (Table 5). This research will add scientific proof to the folkloric use of the Lavendula genus in tissue regeneration. Plant-derived EOs, such as Lavendula, are being used in the treatment of inflammation and burns [10]. Lavender oil, in particular, has a long history of use in wound repair. It has been stated that lavender EOs have a wide range of pharmacological properties that could be beneficial in the wound healing process [46-48]. Antimicrobial agents play a vital part in tissue regeneration. They function as a shield against microbial attacks and protect the injured area from a variety of infections. The wound healing activity of the LSEO could be also attributed to their antimicrobial effects. 
Table 5. The effects of different species of lavender essential oil on wound healing treatment.

\begin{tabular}{|c|c|c|c|c|}
\hline Authors & Country & $\begin{array}{c}\text { Plant } \\
\text { Species }\end{array}$ & Objectives & Main Results \\
\hline $\begin{array}{c}\text { Baali } \\
\text { et al. } \\
{[46]}\end{array}$ & Algeria & $\begin{array}{l}\text { Lavandula } \\
\text { stoechas }\end{array}$ & $\begin{array}{l}\text { - } \\
\text { Determination of the } \\
\text { antibacterial, antioxidant } \\
\text { and wound healing } \\
\text { effects of two methanol } \\
\text { extracts from aerial parts } \\
\text { of Lavandula stoechas and } \\
\text { Mentha pulegium. } \\
\text { The wound healing effect } \\
\text { of ointments containing } \\
5 \% \text { and } 10 \% \text { of } \\
\text { pennyroyal and lavender } \\
\text { was tested in vivo } \\
\text { (Wistar albino rats). }\end{array}$ & 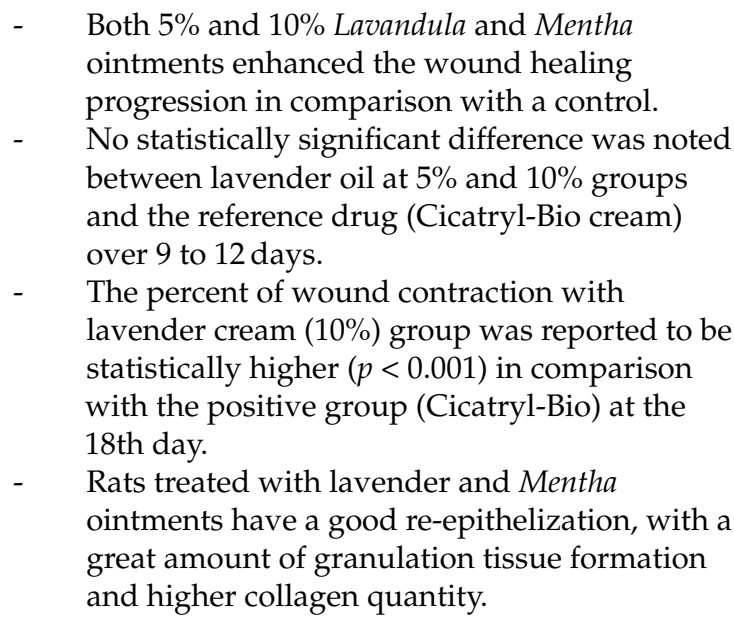 \\
\hline $\begin{array}{c}\text { Kazemi } \\
\text { et al. } \\
\text { [49] }\end{array}$ & Iran & $\begin{array}{l}\text { Lavandula } \\
\text { Angustifolia }\end{array}$ & $\begin{array}{l}\text { Assessment of the effect } \\
\text { of nanoemulsion cream } \\
\text { containing lavender } \\
\text { volatile oil and licorice } \\
\text { extract on the healing of } \\
\text { deep skin wound in an } \\
\text { animal model. }\end{array}$ & $\begin{array}{l}\text { - A nanoemulsion comprising lavender EO and } \\
\text { licorice extract promotes wound healing at } \\
\text { many phases, including wound contraction, } \\
\text { tissue regeneration, and molecular processes } \\
\text { such as increased expression of TGF-1, type I, } \\
\text { and type III collagen genes. } \\
\text { The increased antioxidant activities of } \\
\text { superoxide dismutase and glutathione } \\
\text { peroxidase resulted in lower MDA levels, a } \\
\text { byproduct of lipid peroxidation. } \\
\text { Nanoemulsion of lavender EO significantly } \\
\text { decreased the wound area more than } \\
\text { other groups. }\end{array}$ \\
\hline
\end{tabular}

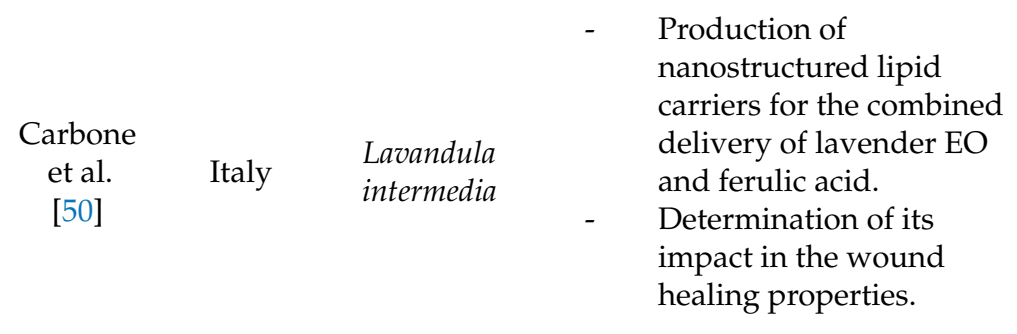

- $\quad$ The mutual delivery of lavender EO and ferulic acid significantly stimulated cell migration with greater efficacy in comparison with the free drug solution and the carrier without the lavender oil.

- The potential combined activity of the lavender oil and the antioxidant ferulic acid co-delivered in nanostructured lipid carriers in helping cell growth and tissue regeneration, demonstrating a potent approach in the wound healing treatment.

- The addition of Lavandula EO and Ag NPs to the nanofiber dressings increased their hydrophilicity and assured the proliferation of chicken embryo fibroblasts cultivated in vitro on these fiber dressings.

- $\quad$ Production of composite electrospun wound-dressing

Sofi
et al. India $\quad \begin{gathered}\text { Lavandula } \\ \text { [51] }\end{gathered}$
nanofibers composed of polyurethane encasing lavender $\mathrm{EO}$ and silver (Ag) nanoparticles (NPs).
- The antimicrobial efficacy of the nanofiber was tested against E. coli and S. aureus, indicating that the dressings had outstanding bactericidal effects.

The composite nanofiber dressings have a high potential for application as multipurpose wound dressings, providing protection against microbes while also stimulating tissue regeneration. 
Table 5. Cont.

\begin{tabular}{|c|c|c|c|c|}
\hline Authors & Country & $\begin{array}{c}\text { Plant } \\
\text { Species }\end{array}$ & Objectives & Main Results \\
\hline $\begin{array}{l}\text { Mori } \\
\text { et al. } \\
{[52]}\end{array}$ & Japan & $\begin{array}{l}\text { Lavandula } \\
\text { angustifolia }\end{array}$ & $\begin{array}{l}\text { Evaluation of the } \\
\text { potential activity of } \\
\text { Lavandula essential oil on } \\
\text { several stages of wound } \\
\text { healing process. } \\
\text { Determination of the } \\
\text { wound healing molecular } \\
\text { mechanism, focusing on } \\
\text { transforming growth } \\
\text { factor- } \beta(\text { TGF- } \beta) \text {. }\end{array}$ & $\begin{array}{l}\text { - The use of lavender EO on the skin increased } \\
\text { collagen production and fibroblast } \\
\text { differentiation, as well as the expression of } \\
\text { TGF- } \beta \text {. } \\
\text { - } \quad \text { Lavender EO has the ability to enhance wound } \\
\text { healing in the early stages by accelerating the } \\
\text { production of granulation tissue, tissue } \\
\text { remodeling through collagen replacement, and } \\
\text { tissue repair via TGF- } \beta \text { upregulation. } \\
\text { At four days after wounding, topical } \\
\text { administration of lavender EO increased the } \\
\text { production of type I and III collagen, as well as } \\
\text { an increase in the number of fibroblasts, which } \\
\text { generate collagen. }\end{array}$ \\
\hline $\begin{array}{l}\text { Ben Djemaa } \\
\text { et al. } \\
\text { [13] }\end{array}$ & Tunisia & $\begin{array}{l}\text { Lavandula } \\
\text { aspic }\end{array}$ & $\begin{array}{l}\text { Determination of the } \\
\text { chemical composition, } \\
\text { antioxidant effect and } \\
\text { in vivo wound healing } \\
\text { properties of Lavandula } \\
\text { aspic EO ointment on } \\
\text { experimentally induced } \\
\text { full-thickness skin } \\
\text { wounds in vivo based on } \\
\text { several of clinical, } \\
\text { biochemical, and } \\
\text { histopathological tests. }\end{array}$ & $\begin{array}{l}\text { - The use of lavender EO ointment was shown to } \\
\text { considerably improve wound contraction (98\%) } \\
\text { and protein production. } \\
\text { - When compared to the control group of } \\
\text { animals, the topical use of lavender ointment } \\
\text { efficiently accelerated tissue repair, improved } \\
\text { antioxidant enzyme concentrations, and } \\
\text { recovered skin tissues. } \\
\text { The findings showed significant evidence for } \\
\text { lavender EO ointment's good wound-healing } \\
\text { effect, making it a good option for potential } \\
\text { development as an active ingredient in tissue. }\end{array}$ \\
\hline $\begin{array}{l}\text { Lusby } \\
\text { et al. } \\
\text { [47] }\end{array}$ & Australia & $\begin{array}{l}\text { Lavandula } \\
\text { allardii }\end{array}$ & $\begin{array}{l}\text { Examinations of whether } \\
\text { two products (EO and } \\
\text { honey) derived from } \\
\text { Lavdandula allardii have a } \\
\text { favorable effect on the } \\
\text { healing of excisional } \\
\text { wounds in vivo. }\end{array}$ & $\begin{array}{l}\text { - Lavandula allardii honey may have beneficial } \\
\text { effects in uninfected wounds. } \\
\text { - Lavandula allardii EO has no therapeutic effect } \\
\text { in uninfected wounds. }\end{array}$ \\
\hline $\begin{array}{l}\text { Momtaz } \\
\text { et al. } \\
\text { [53] }\end{array}$ & Iran & $\begin{array}{l}\text { Lavandula } \\
\text { angustifolia }\end{array}$ & $\begin{array}{l}\text { - } \\
\text { Determination of the } \\
\text { a polyherbal ointment } \\
\text { comprising Lavandula } \\
\text { angustifolia, Rosa } \mathrm{x} \\
\text { damascena, and Althaea } \\
\text { officinalis combination on } \\
\text { wounds caused by third } \\
\text { grade skin cut. }\end{array}$ & $\begin{array}{l}\text { - The } \% \text { of recovery in the polyherbal } \\
\text { formulation group was significantly superior to } \\
\text { other groups. Histological studies also } \\
\text { confirmed these findings. } \\
\text { - Herbal formulation-treated animals presented } \\
\text { important improvement in terms of } \\
\text { re-epithelialization, angiogenesis, collagen } \\
\text { deposition, and decreasing irritation. } \\
\text { The \% of wound healing was } 99 \%, 99.2 \% \text {, and } \\
63.7 \% \text { for the polyherbal formulation, lavender, } \\
\text { and placebo group. }\end{array}$ \\
\hline
\end{tabular}


Table 5. Cont.

\begin{tabular}{|c|c|c|c|c|c|}
\hline Authors & Country & $\begin{array}{c}\text { Plant } \\
\text { Species }\end{array}$ & Objectives & & Main Results \\
\hline $\begin{array}{l}\text { Addis } \\
\text { et al. } \\
{[54]}\end{array}$ & Italy & $\begin{array}{c}\text { Lavandula } \\
\text { stoechas }\end{array}$ & $\begin{array}{l}\text { Evaluation of the effect of } \\
\text { EOs (marigold (Calendula } \\
\text { arvensis), Spanish } \\
\text { lavender (Lavandula } \\
\text { stoechas), and Italian } \\
\text { strawflower (Helichrysum } \\
\text { italicum (Roth) Don } \\
\text { subsp. microphyllum } \\
\text { (Willd.)) on fibroblast } \\
\text { proliferation and in vitro } \\
\text { wound healing } \\
\text { properties. }\end{array}$ & - & $\begin{array}{l}\text { The growth and migration of fibroblasts was } \\
\text { increased as early as } 24 \mathrm{~h} \text { by lavender and } \\
\text { marigold EO compared to control untreated } \\
\text { cells, with a wound closure of } 21.3 \% \text {, and } 21.7 \% \text {, } \\
\text { respectively, when a concentration of } 1 \mu \mathrm{L} / \mathrm{mL} \\
\text { was used. } \\
\text { Wound closure was also promoted after } 48 \text { and } \\
72 \mathrm{~h} \text { of culture with low concentrations ( } 1 \\
\mathrm{~L} / \mathrm{mL} \text { ) of either lavender }(27.4 \% \text { and } 29.2 \%) \text { or } \\
\text { marigold ( } 26.1 \% \text { and } 27.2 \%), \text { both of which } \\
\text { were less effective at higher doses. } \\
\text { EOs are capable of inducing collagen I and III } \\
\text { deposition during wound healing, therefore } \\
\text { accelerating the restoring process. }\end{array}$ \\
\hline $\begin{array}{c}\text { Hajiali } \\
\text { et al. } \\
\text { [55] }\end{array}$ & Italy & Lavandulaangustifolia & $\begin{array}{l}\text { Evaluation of the } \\
\text { combined application of } \\
\text { two natural products } \\
\text { (lavender EO and } \\
\text { sodium alginate) for the } \\
\text { creation of bioactive } \\
\text { nanofibrous coverings by } \\
\text { electrospinning, and } \\
\text { their efficacy for the } \\
\text { management of skin } \\
\text { burns induced by } \\
\text { midrange ultraviolet } \\
\text { radiation (UVB). }\end{array}$ & $\begin{array}{l}- \\
-\end{array}$ & $\begin{array}{l}\text { Nanofibrous dressings containing lavender EO } \\
\text { and sodium alginate oil not only possessed an } \\
\text { inhibitory effect against Staphylococcus aureus } \\
\text { but also successfully inhibited the production } \\
\text { of pro-inflammatory cytokines both in vitro } \\
\text { and in vivo. } \\
\text { Animals exposed to UVB irradiation recovered } \\
\text { quickly and without the appearance of edema } \\
\text { on their injured skin. } \\
\text { Lavender EO had a significant antibacterial } \\
\text { efficacy and also worked to control the skin } \\
\text { inflammation by lipopolysaccharides in human } \\
\text { foreskin fibroblasts and UVB exposure in } \\
\text { rodents. } \\
\text { Dressings have the potential to be advanced } \\
\text { bio-medical systems for burn management. }\end{array}$ \\
\hline $\begin{array}{c}\text { Miastkowska } \\
\text { et al. } \\
{[56]}\end{array}$ & Poland & $\begin{array}{c}\text { Lavandula } \\
\text { angustifolia }\end{array}$ & $\begin{array}{l}\text { Assess the effect of } \\
\text { lavender EO on the } \\
\text { pro-inflammatory and } \\
\text { regenerative activity of } \\
\text { human keratinocytes in } \\
\text { the HaCaT model and } \\
\text { human } \\
\text { monocyte-derived } \\
\text { macrophages. }\end{array}$ & $\begin{array}{l}- \\
-\end{array}$ & $\begin{array}{l}\text { Concentration-dependent induction of } \\
\text { production of IL- } 6 \text { and IL- } 8 \text { by keratinocytes } \\
\text { noticeably augmented during co-stimulation of } \\
\text { cells with the bacterial LPS. } \\
\text { Inflammatory reaction was fine-tuned, as } \\
\text { TNF- } \alpha \text { production in hMDM was limited in the } \\
\text { presence of lavender EO in the LPS-stimulated } \\
\text { macrophages. } \\
\text { The proregenerative response of HaCaT cells } \\
\text { potentiated by the VEGF cytokine was induced. } \\
\text { Lavender EO has a potent potential to improve } \\
\text { the local, tissue-derived pro-inflammatory and } \\
\text { pro-regenerative response, while } \\
\text { simultaneously limiting the inflammatory } \\
\text { stimulation of the immune system cells. } \\
\text { This effect may be linked to the great quantity } \\
\text { of lavandulyl acetate and decreased linalool } \\
\text { acetate. }\end{array}$ \\
\hline
\end{tabular}


Table 5. Cont.

\begin{tabular}{|c|c|c|c|c|}
\hline Authors & Country & $\begin{array}{c}\text { Plant } \\
\text { Species }\end{array}$ & Objectives & Main Results \\
\hline $\begin{array}{c}\text { Panahi } \\
\text { et al. } \\
\text { [57] }\end{array}$ & Iran & $\begin{array}{l}\text { Lavandula } \\
\text { stoechas }\end{array}$ & $\begin{array}{l}\text { Investigation of the ability of } \\
\text { herbal combination cream } \\
\text { containing lavender and } \\
\text { rose-scented geranium EOs } \\
\text { and aloe vera gel in the } \\
\text { improvement of symptoms in } \\
\text { patients with superficial } \\
\text { second-degree burns, in } \\
\text { comparison with silver } \\
\text { sulfadiazine (SSD) } 1 \% \text { cream. }\end{array}$ & $\begin{array}{l}\text { - Trial indicated that the combination cream } \\
\text { made of EOs and aloe vera gel is higher to SSD } \\
1 \% \text { cream in alleviation of pain. } \\
\text { This combination cream may be used as a } \\
\text { natural and potent alternative for SSD cream in } \\
\text { superficial second-degree burns. }\end{array}$ \\
\hline
\end{tabular}

Hartman and Coetzee [58] studied the impact of a combined effect of lavender and chamomile EOs ( $6 \%$ combined dose) on severe wound healing. The authors chose lavender EO for its documented skin-regenerative, antimicrobial, and anti-inflammatory characteristics, and they included chamomile EO for its observed anti-inflammatory and sedative attributes. The research included eight patients with chronic ulcers that had been present for three or more months, five of whom were allowed to treat with the EO blend and three of whom were treated with standard approaches such as Granulex or a boric acid and hydrogen peroxide regimen. Scientists concluded that the wounds treated with the EOs were more rapidly cured by the completion of the study (with a total healing time of 420 days off), with four of five wounds treated with essential oils.

An earlier randomized control experiment on 120 women found that lavender EO substantially decreased pain after episiotomy and erythema of incision sites when compared to a control [48]. Another randomized clinical experiment for episiotomy recently found comparable effects, with a substantial reduction in REEDA (redness, edema, ecchymosis, discharge, and approximation) levels and visual analogue scale score for pain when compared to control [59]. Both clinical investigations indicate that lavender EO has a therapeutic effect on wound healing. Moreover, in both an experimental animal model and a human investigation, topical therapy with lavender EO on aphthous ulceration resulted in a considerable ulcer size decrease as compared to the control [60]. Furthermore, there has been research [61] evaluating the mechanism of action of lavender EO on the wound healing process in an experimental animal model. This study found that topical application of lavender EO accelerated wound closure compared to a control group, which was followed by transcriptional activation of PDGF-A and EGF, which are growth factors that play key roles in the wound recovery process such as tissue repair and regeneration [61]. These clinical investigations and animal studies clearly demonstrate that lavender oil has wound healing properties.

Sheikhan et al. [62] conducted a clinical trial in an Iranian hospital, which supports these findings. At five days post-episiotomy, researchers discovered that the group of women treated with $0.96 \%$ lavender EO had significantly lower pain intensity and REEDA scores $(p<0.001$ and $p<0.001$, respectively) than those treated with betadine. Harpreet et al. [63] tried to compare the recovery of episiotomy wounds in postnatal mothers treated with lavender EO versus betadine. Using the REEDA scale as a comparison, scientists discovered that lavender EO was more efficient in wound healing for the first three days $(p=0.035)$, but by day five $(p<0.05)$, both treatments were equally effective.

Moreover, it has previously been suggested that Lavandula EO may enhance faster wound healing, related to its potential to influence extracellular matrix caused by plateletderived growth factors (PDGFs) and re-epithelialization produced by epidermal growth factors (EGFs) [45]. Our findings are also consistent with those reported by Ben Djemaa et al. [13], who revealed a significant decrease in wound area after using a cream carrying Lavandula EO; the authors hypothesize that this result could be linked to the EO's antibacterial, antifun- 
gal, and anti-inflammatory properties, which are attributed to the presence of oxygenated monoterpenes.

A previous research published in the journal Evidence-Based Complementary and Alternative Medicine examined the efficacy of various wound healing treatments. Transcutaneous electrical nerve stimulation (TENS), lavender EO, saline solution and povidoneiodine were all tested on an experimental animal model. The TENS and lavender EO groups repaired wounds quicker than the control groups. These data imply that lavender has wound-healing booster activity [64].

Han et al. [65] assessed the biological effects of EOs on human dermal fibroblast cells that had been exposed to simulated chronic inflammation. Inflammatory molecular stimuli such as Il-1b, TNF- $\alpha$ and IFN $\gamma$ were used to induce inflammation. A commercial blend of lavender, frankincense, sandalwood, myrrh, Helichrysum, and rose EOs was tested. The researchers found that all of the EOs tested had a significant anti-proliferative effect on fibroblast cells $(p<0.01)$. Furthermore, lavender EO was one of the few oils that inhibited collagen III (a major component of granulation tissue), plasminogen activator inhibitor (PAI-1) (a protein that tends to cause reduced extracellular matrix degradation), and tissue remodeling-related proteins.

\section{Conclusions}

Taken together, our results provide evidence for EOLS's in vivo wound-healing capabilities, implying its use as a bioactive compound in the pharmaceutical and cosmetic industry sectors. Nevertheless, additional research and studies are needed to explore its health benefit on other dimensions of tissue regeneration, such as cytokine production or tissue remodeling at the cellular level, as well as to elucidate and describe the precise mechanism of its pharmacological effect.

Author Contributions: Conceptualization, M.N.B.; data curation, M.N.B.; formal analysis, M.N.B., H.C., F.O.; investigation, M.N.B., A.H., F.B., F.O., and Y.H.; methodology, M.N.B., H.C., F.O.; resources, M.N.B., F.O., H.C.; supervision, M.N.B., H.C., F.O.; validation, M.N.B., F.O.; visualization, F.O., M.N.B., and H.C.; writing—original draft, M.N.B.; writing—review and editing, M.N.B. All authors have read and agreed to the published version of the manuscript.

Funding: This investigation did not receive any particular grant from funding agencies in the commercial, public, or not-for-profit sectors.

Institutional Review Board Statement: The animal study was carried out in compliance with the Algerian Executive Directive (18 March 2004, N ${ }^{\circ} 10-90$ JORA) and accordance also to the Law No. 88-08 of 26 January 1988 relating to veterinary medicine activities and the protection of animal health ( $\mathrm{N}^{\circ}$ JORA: 004 of 27-01-1988).

Informed Consent Statement: Not applicable.

Data Availability Statement: Not applicable.

Acknowledgments: The author would like to thank the "Laboratoire National de Contrôle des Produits Pharmaceutiques" (Algiers) and the "Laboratoire Anatomie Pathologique (CHU Beni Messous, Algiers, Algeria)" for their technical support and assistance.

Conflicts of Interest: The authors declare no conflict of interest. 


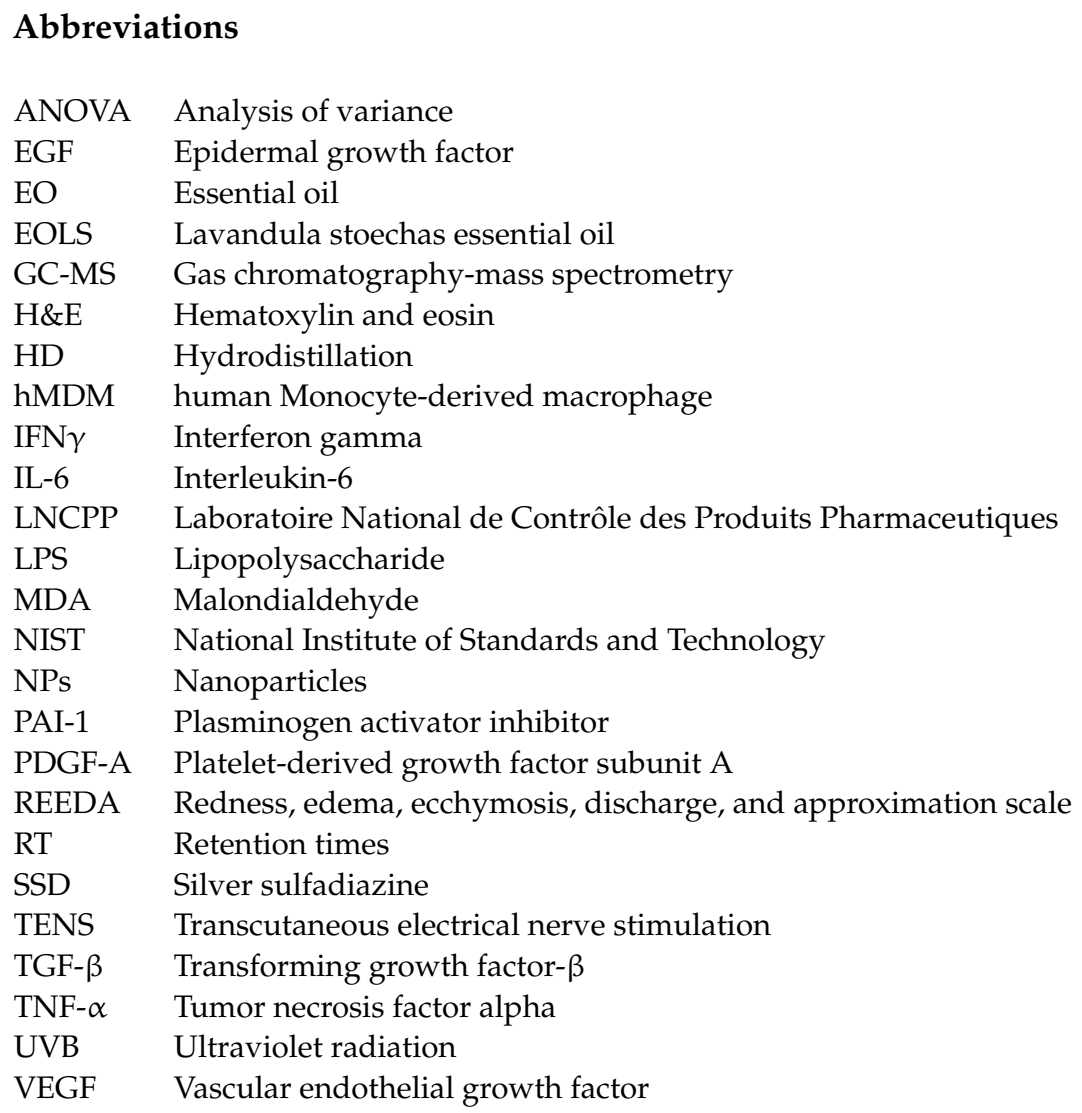

\section{References}

1. Suleyman, H.; Demircan, B.; Karagoz, Y. Anti-inflammatory and side effects of cyclo-oxygenase inhibitors. Pharmacol. Rep. 2007, 59, 247.

2. Bakkali, F.; Averbeck, S.; Averbeck, D.; Idaomar, M. Biological effects of essential oils-A review. Food Chem. Toxicol. 2008, 46, 446-475. [CrossRef]

3. Edris, A.E. Pharmaceutical and therapeutic potentials of essential oils and their individual volatile constituents: A review. Phytother. Res. 2007, 21, 308-323. [CrossRef]

4. Lang, G.; Buchbauer, G. A review on recent research results (2008-2010) on essential oils as antimicrobials and antifungals. A review. Flav. Fragr. J. 2012, 27, 13-39. [CrossRef]

5. Langeveld, W.T.; Veldhuizen, E.J.; Burt, S.A. Synergy between essential oil components and antibiotics: A review. Crit. Rev. Microbiol. 2014, 40, 76-94. [CrossRef]

6. Raut, J.S.; Karuppayil, S.M. A status review on the medicinal properties of essential oils. Ind. Crops Prod. 2014, 62, 250-264. [CrossRef]

7. De Oliveira, M.L.M.; Bezerra, B.M.O.; Leite, L.O.; Girão, V.C.C.; Nunes-Pinheiro, D.C.S. Topical continuous use of Lippia sidoides Cham. essential oil induces cutaneous inflammatory response, but does not delay wound healing process. J. Ethnopharmacol. 2014, 153, 283-289. [CrossRef]

8. Maver, T.; Maver, U.; Stana Kleinschek, K.; Smrke, D.M.; Kreft, S. A review of herbal medicines in wound healing. Int. J. Dermatol. 2015, 54, 740-751. [CrossRef]

9. Keskin, I.; Gunal, Y.; Ayla, S.; Kolbasi, B.; Sakul, A.; Kilic, U.; Ozbek, H. Effects of Foeniculum vulgare essential oil compounds, fenchone and limonene, on experimental wound healing. Biotech. Histochem. 2017, 92, 274-282. [CrossRef]

10. Lis-Balchin, M. Lavender: The Genus Lavandula; CRC Press: London, UK, 2003.

11. Benabdelkader, T. Biodiversité, Bioactivité et Biosynthèse des Composés Terpéniques Volatils des Lavandes Ailées, Lavandula Stoechas Sensu Lato, un Complexe D'espèces MéDiterranéennes D'intérêt Pharmacologique. Ph.D. Thesis, Filière de Biologie, Université Jean Monnet-Saint-Etienne (France) en co-tutelle avec l'Ecole Normale Supérieure de Kouba, Algiers, Algeria, 2012.

12. Cavanagh, H.M.A.; Wilkinson, J.M. Biological activities of lavender essential oil. Phytother. Res. 2002, 16, 301-308. [CrossRef]

13. Ben Djemaa, F.G.B.; Bellassoued, K.; Zouari, S.; El Feki, A.; Ammar, E. Antioxidant and wound healing activity of Lavandula aspic L. ointment. J. Tissue Viab. 2016, 25, 193-200. [CrossRef]

14. Rahmati, B.; Kiasalari, Z.; Roghani, M.; Khalili, M.; Ansari, F. Antidepressant and anxiolytic activity of Lavandula officinalis aerial parts hydroalcoholic extract in scopolamine-treated rats. Pharm. Biol. 2017, 55, 958-965. [CrossRef]

15. Rafiee, M.; Kiani, Z.; Moezi, S.A.; Rad, G.H.M. The Effects of Lavender, Valerian, and Oxazepam on anxiety among hospitalized patients with coronary artery disease. Modern. Care J. 2018, 15, e68390. [CrossRef] 
16. Miraj, S. Lavandula stoechas L: A systematic review of medicinal and molecular perspectives. Der. Pharma. Lett. 2016, 8, 56-58.

17. Süntar, I.; Tumen, I.; Ustün, O.; Keleş, H.; Akkol, E.K. Appraisal on the wound healing and anti-inflammatory activities of the essential oils obtained from the cones and needles of Pinus species by in vivo and in vitro experimental models. J. Ethnopharmacol. 2012, 139, 533-540. [CrossRef]

18. Dob, T.; Dahmane, D.; Agli, M.; Chelghoum, C. Essential oil composition of Lavandula stoechas from Algeria. Pharm. Biol. 2006, 44, 60-64. [CrossRef]

19. Baali, F.; Boumerfeg, S.; Napoli, E.; Boudjelal, A.; Righi, N.; Deghima, A.; Ruberto, G. Chemical Composition and Biological Activities of Essential Oils from Two Wild Algerian Medicinal Plants: Mentha pulegium L. and Lavandula stoechas L. J. Essent. Oil Bear. Plants 2019, 22, 821-837. [CrossRef]

20. Boukhatem, M.N.; Sudha, T.; Darwish, N.H.; Chader, H.; Belkadi, A.; Rajabi, M.; Mousa, S.A. A New Eucalyptol-Rich Lavender (Lavandula stoechas L.) Essential Oil: Emerging Potential for Therapy against Inflammation and Cancer. Molecules 2020, $25,3671$. [CrossRef]

21. Yakoubi, R.; Megateli, S.; Sadok, T.H.; Bensouici, C.; Bağci, E. A synergistic interactions of Algerian essential oils of Laurus nobilis L., Lavandula stoechas L. and Mentha pulegium L. on anticholinesterase and antioxidant activities. Biocatal. Agric. Biotechnol. 2021, 31, 101891. [CrossRef]

22. Loukhaoukha, R.; Saidi, F.; Jullien, F.; Benabdelkader, T. Chemical Composition and Antibacterial Activity of Lavandula Stoechas Essential Oil and Its Main Components against Erwinia Amylovora and Pectobacterium Carotovorum Subsp. Carotovorum. Phytothérapie 2018, 16, 149-157. [CrossRef]

23. Barkat, M.; Laib, I. Antioxidant activity of the essential oil from the flowers of Lavandula stoechas. J. Pharmacogn. Phytother. 2012, 4, 96-101.

24. Kokkalou, E. The constituents of the essential oil from Lavandula stoechas growing wild in Greece. Planta Med. 1988, 54, 58-59. [CrossRef] [PubMed]

25. Skoula, M.; Abidi, C.; Kokkalou, E. Essential oil variation of Lavandula stoechas L. ssp. stoechas growing wild in Crete (Greece). Biochem. Syst. Ecol. 1996, 24, 255-260. [CrossRef]

26. Ristorcelli, D.; Tomi, F.; Casanova, J. 13C-NMR as a tool for identification and enantiomeric differentiation of major terpenes exemplified by the essential oil of Lavandula stoechas L. ssp. stoechas. Flav. Fragr. J. 1997, 13, 154-158. [CrossRef]

27. Zuzarte, M.; Gonçalves, M.J.; Cavaleiro, C.; Cruz, M.T.; Benzarti, A.; Marongiu, B.; Salgueiro, L. Antifungal and anti-inflammatory potential of Lavandula stoechas and Thymus herba-barona essential oils. Ind. Crops Prod. 2013, 44, 97-103. [CrossRef]

28. Domingues, J.; Delgado, F.; Gonçalves, J.C.; Pintado, C.S. Essential Oils of Lavandula stoechas subsp. luisieri as Antifungal Agent against Fungi from Strawberry Tree Fruit. J. Pharm. Pharmacol. 2021, 9, 98-106.

29. Messaoud, C.; Chograni, H.; Boussaid, M. Chemical composition and antioxidant activities of essential oils and methanol extracts of three wild Lavandula L. species. Nat. Prod. Res. 2012, 26, 1976-1984. [CrossRef]

30. Msaada, K.; Salem, N.; Tammar, S.; Hammami, M.; Jamal Saharkhiz, M.; Debiche, N.; Marzouk, B. Essential oil composition of Lavandula dentata, L. stoechas and L. multifida cultivated in Tunisia. J. Essent. Oil Res. Bear. Plants 2012, 15, 1030-1039. [CrossRef]

31. Akgün, N.A.; Akgün, M.; Dinçer, S.; Akgerman, A. Supercritical fluid extraction of Lavandula stoechas L. ssp. cariensis (Boiss.) Rozeira. J. Essent. Oil Res. 2001, 13, 143-148. [CrossRef]

32. Giray, E.S.; Kırıcı, S.; Kaya, D.A.; Türk, M.; Sönmez, Ö.; Inan, M. Comparing the effect of sub-critical water extraction with conventional extraction methods on the chemical composition of Lavandula stoechas. Talanta 2008, 74, 930-935. [CrossRef]

33. Kırmızıbekmez, H.; Demirci, B.; Yeşilada, E.; Başer, K.H.C.; Demirci, F. Chemical composition and antimicrobial activity of the essential oils of Lavandula stoechas L. ssp. stoechas growing wild in Turkey. Nat. Prod. Commun. 2009, 4, 1934578 X0900400727.

34. Gören, A.C.; Topçu, G.; Bilsel, G.; Bilsel, M.; Aydoğmusç, Z.; Pezzuto, J.M. The chemical constituents and biological activity of essential oil of Lavandula stoechas ssp. stoechas. Z. Nat. C 2002, 57, 797-800. [CrossRef] [PubMed]

35. Bozkurt, İ.A.; Soylu, S.; Kara, M.; Soylu, E.M. Chemical composition and antibacterial activity of essential oils isolated from medicinal plants against gall forming plant pathogenic bacterial disease agents. Kahramanmaraş Sütçü İmam Üniversitesi Tarım ve Doğa Derg. 2020, 23, 1474-1482.

36. Karan, T. Metabolic profile and biological activities of Lavandula stoechas L. Cell. Mol. Biol. 2018, 64, 1-7. [CrossRef]

37. Cherrat, L.; Espina, L.; Bakkali, M.; Pagán, R.; Laglaoui, A. Chemical composition, antioxidant and antimicrobial properties of Mentha pulegium, Lavandula stoechas and Satureja calamintha Scheele essential oils and an evaluation of their bactericidal effect in combined processes. Innov. Food Sci. Emerg. Technol. 2014, 22, 221-229. [CrossRef]

38. Khavarpour, M.; Vahdat, S.M.; Moghadamnia, A.A.; Hasanzadeh, O.; Salimi, Z.; Rahmanpour, N. Chemical composition, antibacterial and analgesic activity of Lavandula stoechas flowers from north of Iran. Int. J. Eng. 2019, 32, 1065-1073.

39. Asghari, J.; Sadani, S.; Ghaemi, E.; Mazaheri Tehrani, M. Investigation of composition and antimicrobial properties of Lavandula stoechas essential oil using disk diffusion and broth microdilution. Med. Lab. J. 2016, 10, 53-58. [CrossRef]

40. Chebil, B.; Achouri, M.; Idrissi Hassani, L.M.; Hmamouchi, M. Chemical composition and antifungal activity of essential oils of seven Moroccan Labiatae against Botrytis cinerea Pers: Fr. J. Ethnopharmacol. 2003, 89, 165-169.

41. Vokou, D.; Chalkos, D.; Karamanlidou, G.; Yiangou, M. Activation of soil respiration and shift of the microbial population balance in soil as a response to Lavandula stoechas essential oil. J. Chem. Ecol. 2002, 28, 755-768. [CrossRef] 
42. Danh, L.T.; Triet, N.D.A.; Zhao, J.; Mammucari, R.; Foster, N. Comparison of chemical composition, antioxidant and antimicrobial activity of lavender (Lavandula angustifolia L.) essential oils extracted by supercritical $\mathrm{CO}_{2}$, hexane and hydrodistillation. Food Bioproc. Technol. 2013, 6, 3481-3489. [CrossRef]

43. Granger, R.; Passet, J.; Teulade-Arbousset, G. A propos d'une labiée cosmopolite: LaVandula stoechas L. Trav. Soc. Pharm. Montp. 1973, 33, 335-360.

44. Demasi, S.; Caser, M.; Lonati, M.; Cioni, P.L.; Pistelli, L.; Najar, B.; Scariot, V. Latitude and altitude influence secondary metabolite production in peripheral alpine populations of the Mediterranean species Lavandula angustifolia Mill. Front. Plant Sci. 2018, 9, 983. [CrossRef]

45. Hassiotis, C.N.; Ntana, F.; Lazari, D.M.; Poulios, S.; Vlachonasios, K.E. Environmental and developmental factors affect essential oil production and quality of Lavandula angustifolia during flowering period. Ind. Crops Prod. 2014, 62, 359-366. [CrossRef]

46. Baali, F.; Boumerfeg, S.; Boudjelal, A.; Denaro, M.; Ginestra, G.; Baghiani, A.; Trombetta, D. Wound-healing activity of Algerian Lavandula stoechas and Mentha pulegium extracts: From traditional use to scientific validation. Plant Biosyst. 2021, 1-20. [CrossRef]

47. Lusby, P.E.; Coombes, A.L.; Wilkinson, J.M. A comparison of wound healing following treatment with Lavandula $\mathrm{x}$ allardii honey or essential oil. Phytother. Res. 2006, 20, 755-757. [CrossRef] [PubMed]

48. Vakilian, K.; Atarha, M.; Bekhradi, R.; Chaman, R. Healing advantages of lavender essential oil during episiotomy recovery: A clinical trial. Complement. Ther. Clin. Pract. 2011, 17, 50-53. [CrossRef]

49. Kazemi, M.; Mohammadifar, M.; Aghadavoud, E.; Vakili, Z.; Aarabi, M.H.; Talaei, S.A. Deep skin wound healing potential of lavender essential oil and licorice extract in a nanoemulsion form: Biochemical, histopathological and gene expression evidences. J. Tissue Viability 2020, 29, 116-124. [CrossRef]

50. Carbone, C.; Caddeo, C.; Grimaudo, M.A.; Manno, D.E.; Serra, A.; Musumeci, T. Ferulic Acid-NLC with Lavandula essential oil: A possible strategy for wound-healing? Nanomaterials 2020, 10, 898. [CrossRef] [PubMed]

51. Sofi, H.S.; Akram, T.; Tamboli, A.H.; Majeed, A.; Shabir, N.; Sheikh, F.A. Novel lavender oil and silver nanoparticles simultaneously loaded onto polyurethane nanofibers for wound-healing applications. Int. J. Pharm. 2019, 569, 118590. [CrossRef] [PubMed]

52. Mori, H.M.; Kawanami, H.; Kawahata, H.; Aoki, M. Wound healing potential of lavender oil by acceleration of granulation and wound contraction through induction of TGF- $\beta$ in a rat model. BMC Complement. Altern. Med. 2016, 16, 1-11. [CrossRef]

53. Momtaz, S.; Abdolghaffari, A.; Jasemi, E.; Yaghoobvand, B.; Esmaeilzadeh, S.; Abdollahi, A.; Abdollahi, M. Evaluation of wound healing and anti-inflammatory activities of a herbal ointment consisting of Althaea officinalis, Lavandula angustifolia, and Rosa $\mathrm{x}$ damascena in animal excision wound model. J. Med. Plants 2020, 20, 37-49.

54. Addis, R.; Cruciani, S.; Santaniello, S.; Bellu, E.; Sarais, G.; Ventura, C.; Pintore, G. Fibroblast proliferation and migration in wound healing by phytochemicals: Evidence for a novel synergic outcome. Int. J. Med. Sci. 2020, 17, 1030. [CrossRef]

55. Hajiali, H.; Summa, M.; Russo, D.; Armirotti, A.; Brunetti, V.; Bertorelli, R.; Mele, E. Alginate-lavender nanofibers with antibacterial and anti-inflammatory activity to effectively promote burn healing. J. Mater. Chem. B 2016, 4, 1686-1695. [CrossRef]

56. Miastkowska, M.; Kantyka, T.; Bielecka, E.; Kałucka, U.; Kamińska, M.; Kucharska, M.; Cudzik, K. Enhanced Biological Activity of a Novel Preparation of Lavandula angustifolia Essential Oil. Molecules 2021, 26, 2458. [CrossRef] [PubMed]

57. Panahi, Y.; Beiraghdar, F.; Akbari, H.; Bekhradi, H.; Taghizadeh, M.; Sahebkar, A. A herbal cream consisting of Aloe vera, Lavandula stoechas, and Pelargonium roseum as an alternative for silver sulfadiazine in burn management. Asian Biomed. 2012, 6, 273-278.

58. Hartman, D.; Coetzee, J.C. Two US practitioners' experience of using essential oils for wound care. J. Wound Care 2002, 11, 317-320. [CrossRef] [PubMed]

59. Marzouk, T.; Barakat, R.; Ragab, A.; Badria, F.; Badawy, A. Lavender-thymol as a new topical aromatherapy preparation for episiotomy: A randomised clinical trial. J. Obstet. Gynaecol. 2015, 35, 472-475. [CrossRef] [PubMed]

60. Altaei, D.T. Topical lavender oil for the treatment of recurrent aphthous ulceration. Am. J. Dent. 2012, 25, 39-43. [PubMed]

61. Koca Kutlu, A.; Çeçen, D.; Gürgen, S.G.; Sayın, O.; Çetin, F. A comparison study of growth factor expression following treatment with transcutaneous electrical nerve stimulation, saline solution, povidone-iodine, and lavender oil in wounds healing. Evid. Based Complement. Alternat. Med. 2013. [CrossRef]

62. Sheikhan, F.; Jahdi, F.; Khoei, E.M.; Shamsalizadeh, N.; Sheikhan, M.; Haghani, H. Episiotomy pain relief: Use of Lavender oil essence in primiparous Iranian women. Complement. Ther. Clin. Pract. 2012, 18, 66-70. [CrossRef]

63. Harpreet, K.; Monika, K.B. A study to assess the effectiveness of lavender oil versus povidine iodine on healing of episiotomy wound among postnatal mothers. Indian J. Public Health Res. Dev. 2016, 7, 3.

64. Martins, S.; Sarmento, B.; Ferreira, D.C.; Souto, E.B. Lipid-based colloidal carriers for peptide and protein delivery-Liposomes versus lipid nanoparticles. Int. J. Nanomed. 2007, 2, 595-607.

65. Han, X.; Beaumont, C.; Stevens, N. Chemical composition analysis and in vitro biological activities of ten essential oils in human skin cells. Biochim. Open 2017, 5, 1-7. [CrossRef] [PubMed] 